brazilianpoliticalsciencereview

FORUM 2014 ELECTIONS

\title{
The 2014 Elections and the Brazilian Party System*
}

\author{
Carlos Ranulfo Melo \\ Universidade Federal de Minas Gerais, Brazil
}

\begin{abstract}
The Brazilian party system presents a paradox. Although the Workers Party (PT) and the Brazilian Social Democratic Party (PSDB) have controlled presidential elections for the last 20 years, their force at the other levels of electoral competition has not grown. The objective of this study is to undertake a discussion of this situation through the 2014 general elections. After attempting to explain why successive challengers have not been able to change the structure of competition for the Brazilian presidency, I will analyze the relation established between the pattern observed at this level and the other "connected" electoral disputes-both those for state executive and federal legislative office. The general conclusion is that even if the pattern continues, it is quite improbable that this will significantly impact the other levels of national political party competition.
\end{abstract}

Keywords: Presidential elections; competition structure; Brazilian party system.

I magine a country with little political party tradition, where parties are relatively recent and organizationally fragile; where the majority of the electorate is more accustomed to valuing individual candidates than the available party labels and do not identify with any of them. Now add to this the fact that for the sixth consecutive time, the same two parties dominated the presidential election and one of them won the last four disputes.

There is something strange about these two things. It would not be so strange if the parties, in this case the Workers Party (PT) and the Brazilian Social Democratic Party (PSDB), were also the two largest national parties; however, they

(*) http://dx.doi.org/10.1590/1981-38212014000200004

The author would like to express his thanks for the comments and suggestions of anonymous colleagues of the Brazilian Political Science Review. 
are not. Combined, they elected $24.1 \%$ of city mayors in 2012, and in 2015, they managed to control $19.4 \%, 24.1 \%, 22.2 \%$ and $37.0 \%$ of the seats in the state legislative assemblies, the federal Chamber of Deputies, the Federal Senate, and of state governorships, respectively.

Beginning with this description, the objective of this study is to use the 2014 general elections to undertake the discussion about the Brazilian political party system. Basically, we seek to inquire why the pattern of presidential elections has continued and to ask about their impact on elections for state governorships, for the Federal Congress, and for State legislatures.

In general, we intend to argue that even with a high probability that the current structure of competition for the presidency continues, it is very unlikely that this will have a significant impact on the other levels of political party competition in the country. The argument is developed in three sections. In the first section, we focus on the presidential level and seek to indicate why the PT and PSDB have persisted while the other parties have abandoned the arena or have witnessed defeat of their candidates. In the second section, we focus on state level politics to discuss the prospects for "presidentialization" of the elections for governor. In the third section, we concentrate on legislative elections and try to examine the present discussion in the literature regarding the impact of majority elections over proportional ones in the context of Brazil. The conclusion summarizes the arguments briefly.

\section{Presidential elections and the third way}

It is generally known (COX, 1997; DUVERGER, 1987) that majority disputes reduce the number of competitors effectively, either because the "entry cost" of the dispute is high and parties may prefer other strategies to obtain political advantage, or because the electorate tends to choose from among those who possess a greater chance of winning. Indeed, this does not define who these competitors will be, whether the situation will stabilize or if, on the contrary, during each election the "effective" competitors will vary. And even if the situation is stable, the possibility remains that there might be a change in the "structure of competition"(MAIR, 1996; 2006). 
In Brazil, the period between 1985 and 1994 was characterized by intense fluidity in party politics because of the appearance of many parties and an intense migration of legislators between the existing parties. However, this situation was overcome as competition for the presidency acquired a certain format: beginning in 1994 it became possible to foresee how the dispute for the federal government would appear and also the protagonists of this dispute. Table 01 indicates some data about the Brazilian presidential elections indicating the context of stability under the hegemony of the PT and the PSDB.

Table 01. Presidential elections: candidates, \% of votes (1st round) and volatility

\begin{tabular}{cccccccc} 
& \multicolumn{7}{c}{ Election Year } \\
\cline { 2 - 7 } & 1989 & 1994 & 1998 & 2002 & 2006 & 2010 & 2014 \\
\hline $\begin{array}{c}\text { Absolute number of } \\
\text { candidates }\end{array}$ & 21 & 08 & 12 & 06 & 07 & 09 & 11 \\
$\begin{array}{c}\text { Effective number of } \\
\text { candidates }\end{array}$ & 5.7 & 2.7 & 2.5 & 3.2 & 2.4 & 2.8 & 3.0 \\
$\begin{array}{c}\text { \% PT votes } \\
\text { \% PSDB votes }\end{array}$ & 17.5 & 27.0 & 31.7 & 46.4 & 48.6 & 46.9 & 41.6 \\
PT + PSDB & 11.5 & 54.4 & 53.1 & 23.2 & 41.6 & 32.6 & 33.6 \\
Volatility* & 28.7 & 81.4 & 84.8 & 69.6 & 90.2 & 79.5 & 75.1 \\
& & 58.6 & 17.8 & 33.6 & 30.4 & 20.4 & 24.3
\end{tabular}

Source: calculations by the author using Federal Election Commission data.

*Calculated according to the index proposed by Pedersen. The value 58.6 corresponds to the result of applying the index to the pair 1989/1994 and so forth.

The 1989 presidential election clearly expressed the period of fluidity as aforementioned: It occurred amidst the crisis of the Party of the Brazilian Democratic Movement (PMDB) and its alliance with the then Party of the Liberal Front $(\mathrm{PFL})^{1}$, and the dispute ended up polarized by PT and the Party of National Reconstruction (PRN) that, together, held less than $4 \%$ of seats in the House of Representatives. However, its result managed to define the dispute between the Worker's Party and the Democratic Labour Party (PDT), as to which of them would be the challenging party in the scenario established after the return to democracy.

1 The crisis of the PMDB began with the deterioration of the José Sarney administration (1985-1990). The PFL changed its name in 2007 to "Democratas" (DEM). 
Five years later, Leonel Brizola would discover that most of his electorate had migrated to Lula ${ }^{2}$.

On the other hand, the 1994 election guaranteed the PSDB a firm place in disputes for the presidency based on two related actions. The first was the successful and significant introduction of economic stability and fiscal austerity on the national agenda. The second was a relative shift of an ideological nature toward the right (ROMA, 2002) to celebrate an alliance with the PFL and the Brazilian Labour Party (PTB) ${ }^{3}$. The party would present a political platform capable of representing the establishment, reduce the space for candidates located on the right, and assume the central role that had belonged to the PMDB in the process of transition to democracy (MELO, 2010). The years 1989 and 1994 witnessed critical events: by crystallizing the positions of the PT and the PSDB they had a decisive impact on the subsequent dynamic of presidential disputes.

However, critical situations demand a "reproductive mechanism" (THELEN, 1999) for the persistence of their legacies. This mechanism may be observed in the capacity demonstrated by the PT and the PSDB to (a) maintain coherence on national political platforms; (b) present competitive candidates; (c) provide them the necessary coverage, ensuring them support in states and municipalities, and (d) devise the strategy of other levels of electoral competition based on the national objective.

One should note that these factors are not associated with election campaigns per se. In fact predate them. And at the same time go beyond, because they must be kept in time to be effective. It is precisely this challenge-combining these factors and doing so through time-that helps explain why the largest national parties abandoned the idea of presidential disputes and why all "third way" candidates have failed since 1994.

Among the parties that have foregone such disputes, the PMDB undoubtedly represents the most emblematic of cases. With a broad and extensive presence through a high number of elected governors, senators, representatives,

\footnotetext{
2 Brizola (PDT) won $16.2 \%$ of votes in the first round in 1989 , and only $3.2 \%$ in 1994 . In the same period, Lula jumped from $17.5 \%$ to $27 \%$ of valid votes.

3 Today, the PTB is on the right of the Brazilian party spectrum. In the dispute for taking up the Brazilian labor banner Leonel Brizola lost control of the name in the courts and ended up bringing together the more left-leaning sectors on the PDT.
} 
and mayors, the largest Brazilian political party suffered resounding defeats in the 1989 and 1994 elections. The defeat in the first election with Ulysses Guimarães could be credited to the absence of a platform to separate it from the discredited Sarney administration and could present something new to the country; five years later, Orestes Quércia would find his own candidacy to be left to its own devices while at the regional level, his party supported the PSBD candidate, Fernando Henrique Cardoso. In summary, the absence of leaders with the potential to entrench themselves in the various regional currents of the party and to qualify such interests as a national strategy would be characteristic of the inability to formulate and to unify around a national political platform, something evident since the formation of the Constituent Assembly. Since then, it was apparent to the leadership that the best way to exploit the party's potential was not to be observed in the launching of their own candidate in presidential elections-an option that would demand an unavailable degree of coordination and centralization-but rather in state disputes, a path that would guarantee strong representation in the National Congress and, consequently, ascendance to the President of the Republic.

The trajectory of the former Liberal Front Party (PFL), now called Democratas (DEM) is also emblematic of parties that have resigned to contest for the presidency. The second largest party of the country in 1989, its candidate won only $0.9 \%$ of votes in the presidential election of that year, and since then, it has supported the PSDB candidate. However, in 2002, another alternative appeared. After electing seven governors in 1998, the largest number of members of the Chamber of Deputies and the second largest of the Senate, the party was at the peak of its trajectory. Politically cohesive and possessing a defined political perspective, the party took advantage of certain conditions to launch its own candidate and to be a part of the competition to succeed FHC as the "major partner" of the center-right coalition. The strategy did not move forward because its candidacy was torpedoed in the beginning of 2002 in an obscure operation by the Federal Police (MEIRA, 2013). From that time on, the party, in opposition to PT administrations, lost competitiveness and definitely did not possess the potential to singularly run for the presidency any longer.

Besides the PDT, the Progressive Party (PP) was another party of considerable influence at the beginning of the 1990s that abandoned the 
presidential arena ${ }^{4}$. After a reasonable performance in 1989 (8.9\% of the votes), its weak showing in 1994 (2.7\%) was interpreted as evidence that it was not worthwhile to dispute the leading role of the right in the political spectrum. Since then, the party has centered its strategy on electing members to Congress and then negotiating support first with the PSDB and subsequently with the PT administrations.

On two occasions, in 2002 and 2014, the hegemony of the PT and the PSDB appeared to be under threat. On both occasions, an opportunity arose due to the difficulty suffered by one of the competitors, in the case of the PSDB, to consolidate its candidacy. On the first occasion, José Serra (PSDB) was only able to attain second place in the September preference polls following the beginning of the period of free political advertising on the radio and television. Until then, Garotinho (Brazilian Socialist Party - PSB) and Ciro Gomes (Popular Socialist Party - PPS) had taken turns being the chief threats to Lula (MEIRA, 2013). However, it was in the 2014 election, first with Eduardo Campos (PSB) and then with Marina Silva, that the talk about a third way emerged with greater chances of its realization.

Ciro, as well as Garotinho and Marina-the latter running as a candidate of the Green Party, PV, in 2010 and the PSB in 2014-portrayed themselves to be competitive $^{5}$. The advantage of Marina Silva over the first two candidates was apparent in two areas. First, it was her capacity to clearly express something that appeared to be "new politics". Seeing that the PT and PSDB were able to benefit from expectations generated within the electorate and to be identified with alternative political platforms, a crucial challenge to any competitor was of making an impact on the electoral competition through the introduction of a new focus of discussion and, offer the electorate a good reason to change its vote through this. Emerging as the big news of the 2010 elections, in 2014, Marina was able to

\footnotetext{
${ }^{4}$ The party is the current successor of the PDS, a party that came out of ARENA, which was responsible for supporting the military regime after 1964 .

5 Marina broke with the PT in 2009 and disputed her first presidential election under the banner of the PV in 2010. She later began building a new party, the Sustainability Network which, however, was unable to fulfill the registration requirements demanded by the National Election Commission in time to qualify for the election of 2014. In the face of this impasse, Marina and her group decided to affiliate with the PSB, the party that had offered her the Vice Presidential slot on the ticket of Eduardo Campos. With the death of the latter at the beginning of the campaign, Marina became the candidate of the PSB.
} 
continue the discourse of Eduardo Campos regarding the need to break away from the "old" PT/PSDB polarization.

Second, the PSB candidate had greater capillarity in 2014 than in 2010. Table 02, below, provides data that allows us to compare the opposing candidacies launched by the PPS (1998 and 2002), the PSB (2002 and 2014), and the PV (2010) to those presented by the PT and $\mathrm{PSDB}^{6}$. As a way of measuring the extent of presence of the candidates, we chose to compare the number of candidacies launched by parties themselves and of coalitions established in elections for state governorships. For both categories, we computed only the cases in which the candidates and coalitions showed themselves to be competitive; that is, cases in which they surpassed $10 \%$ of valid votes cast ${ }^{7}$. In addition, we considered the number of council members and mayors elected by the parties that composed each of the presidential coalitions in the municipal elections held two years beforehand.

As can be observed, the difference between the PT and the PSDB, on the one hand, and the challengers, on the other hand, were more pronounced in 1998 and 2010. In 1998, the launching of the candidacy of Ciro Gomes by the PPS was not accompanied by any competitive candidacy for state governorships. Moreover, the party did not manage to form an electoral coalition for President. Thus, the number of mayors and council members who could potentially be mobilized turned out to be very small. A similar situation can be observed in 2010, when the PV did not participate in coalitions. By 2002, Ciro's coalition (PPS/PDT/PTB) had more representatives elected in municipalities in 2000 than that of Lula (PT/PL/PCdoB), although the PPS remained well behind in terms of the number of candidacies launched and of competitive coalitions in which it participated. The other challenger, the PSB, was in a slightly better condition in terms of the number of its own candidacies; however, the same cannot be said with regard to the other

\footnotetext{
6 The 2006 election was not included in the table because on that occasion the challenging candidate (Heloísa Helena of the Socialism and Liberty Party-PSOL) obtained only 6.8\% of the votes.

7 Any level that might be established to define the competitiveness of a candidacy or coalition could be considered as arbitrary. A level of $15 \%$, for example, might be too high when for situations in which three candidates dispute an election within a context in which voter intentions frequently oscillate. It thus makes sense to suppose that in a great many campaign situations in Brazil, exceeding the $10 \%$ mark functions as a kind of signal, whether for other candidates or for voters, that a particular candidacy should be considered.
} 
categories. With the 2010 and 2014 elections, the broadening of PT alliances contributed to increasing the contingent of council members and mayors who, at least in theory, were available for the campaign of Dilma Rousseffe. Finally, in 2014, the candidacy of Marina Silva, thanks to the groundwork previously laid by Eduardo Campos, gained more support in the states than the other challengers in previous elections.

Table 02. Presidential candidacies and the extent of party presence in states and municipalities

\begin{tabular}{|c|c|c|c|c|c|}
\hline \multirow[t]{2}{*}{ Party } & \multirow[t]{2}{*}{ Year } & \multirow{2}{*}{$\begin{array}{c}\text { Party's own } \\
\text { competitive } \\
\text { candidacy in states }\end{array}$} & \multirow{2}{*}{$\begin{array}{l}\text { Participation in } \\
\text { competitive } \\
\text { coalition* }\end{array}$} & \multicolumn{2}{|c|}{$\begin{array}{l}\text { Elected by the presidential } \\
\text { coalition in the previous } \\
\text { municipal election }\end{array}$} \\
\hline & & & & Mayors & Council Members \\
\hline PSDB & & 10 & 11 & 2,287 & 19,042 \\
\hline PT & 1998 & 14 & 16 & 312 & 5,444 \\
\hline PPS & & 0 & 11 & 32 & 330 \\
\hline PSDB & & 11 & 09 & 2,248 & 15,952 \\
\hline PT & 2002 & 20 & 01 & 436 & 4,367 \\
\hline PPS & & 03 & 06 & 853 & 8,893 \\
\hline PSB & & 08 & 01 & 135 & 1,326 \\
\hline PSDB & & 13 & 06 & 1,829 & 16,792 \\
\hline PT & 2010 & 14 & 06 & 2,951 & 24,048 \\
\hline PV & & 01 & 07 & 75 & 1,237 \\
\hline PSDB & & 11 & 08 & 1.369 & 14,174 \\
\hline PT & 2014 & 16 & 14 & 3.349 & 31,778 \\
\hline PSB & & 08 & 09 & 637 & 7,480 \\
\hline
\end{tabular}

Source: calculations by the author using Federal Election Commission data.

*For the coalitions I did not compute cases in which a party participates in a coalition headed by one of its competitors on the federal level.

Be that as it may, even in 2014 , the gap between competitors was very large. Another piece of data related to the territorial organization of parties helps to complete the picture: according to Ribeiro (2013), in 2012, the organizational map of the PT covered $96.7 \%$ of Brazil's territory, and in $82.5 \%$ of municipalities the party had Municipal Directorates, with the rest being in the charge of Provisional Commissions. The PMDB, the principal ally of the PT, was organized in

8 In 2010, the PMDB was formally allied to the PT in a presidential election for the first time. The coalition was composed of the Republican Party (PR) and the Brazilian Republican Party (PRB), as well as the PDT, PSB, and the Communist Party of Brazil (PcdoB). In 2014, the coalition lost the PSB but was able to obtain the adhesion of the PP and of the Social Democratic Party (PSD), which was created in 2011 through the initiative of former São Paulo mayor Gilberto Kassab. 
$88.6 \%$ of the country, with $68.1 \%$ of the cases corresponding to Directorates. On the other hand, coverage of the PSB reached 77.3\%, but of this total, the proportion of Directorates constituted only 17.9\%, which denotes a much weaker party structure $^{9}$. A similar picture can be observed with the PPS, which in 2014 supported Marina Silva: It is organized in $61.4 \%$ of the country, and the party possessed Directorates in only $14.5 \%$ of its municipalities. For its part, the PSDB extended its organizational network over $86.0 \%$ of the country, with $54.1 \%$ of the cases corresponding to Directorates. Its principal ally, the Democrats, were organized in $74.9 \%$ of the country and had Directorates in $25 \%$ of the municipalities in which it held a presence.

Certainly, the data presented here does not allow us to rigorously verify the impact the extent of presence had on the votes obtained by candidates. But they do remind us, in agreement with the literature (LIMA JUNIOR, 1999), that the success of presidential candidacies in Brazil has always kept relation with the construction of political bases throughout the entire country. Today, speech platforms constructed in states, council members and mayors mobilized in cities, and municipal directorates organized around the country can fulfill important roles as instruments for reproduction of an electoral campaign linked to the radio and television. Thus, although it is not possible to make any categorical statement in this regard, it seems logical that the weaker presence of the PSB contributed to the weakness of its candidacy at the end of the first round of the 2014 elections. It is evident in the data organized by the Folha de São Paulo newspaper which indicate that voting for Marina Silva fell in a linear fashion according to the size of the electorate, falling from $29.5 \%$ in municipalities with more than 500,000 voters to $13.9 \%$ in those with fewer than 50,000 . In contrast, votes for Dilma demonstrate the opposite trend, rising as well in a linear fashion, from $33.9 \%$ in regions with high voter density to $53.7 \%$ of votes in the "backwoods" 10 .

\footnotetext{
9 The existence of a municipal directorate indicates a greater degree of institutionalization by the party, given that its election requires a minimum number of members and the holding of a municipal meeting. For their part, provisional commissions may be appointed by the higher ranks of the party that in so doing merely send a series of names to the election authorities.

10 www1.folha.uol.com.br. The complete data for Marina are: 500,000 voters $(29.3 \%)$; 200,000 to 500,000 (27.8\%); 100,000 to 200,000 (24.0); 50,000 to 100,000 (19.1\%), and fewer than $50,000(13,9 \%)$. For Dilma, the vote percentages over the same sequence were:
} 
Finally, to understand why Marina did not reach the second round of the presidential election of 2014, one should also consider the fact that her candidacy (a) was not able to sustain the "novelty" presented to the voter in a convincing manner when faced with a swarm of criticism, and (b) she had problems articulating such a "novelty" with the support aggregated by Eduardo Campos. The case of São Paulo illustrates the last point. Research conducted by DataFolha from September 8-911, when Marina was in a technical tie with Dilma, indicates that São Paulo was the state in which the PSB candidate had the best performance: $40 \%$ of voter intentions vs. $16 \%$ for Aécio Neves. As is known, the running mate of Geraldo Alckmim (PSDB) belonged to the PSB, but Marina resisted associating herself directly with the governor/candidate. In the last week of September, surveys began to record the decline of Marina and the rise of Aécio in the state. On election day, the PSDB candidate received $44.2 \%$ of the votes, while the PSB candidate received $25.1 \%$.

\section{State disputes "presidentialized"?}

In recent years, the literature has analyzed the extent to which the pattern assumed by the competition for the presidency of the republic is able to influence the various state party dynamics (MELO, 2010, and to be published: CORTEZ, 2012; FREITAS AND NETO, 2014; LIMONGI and CORTEZ, 2010 ). The data for 2014 allow the discussion to be updated.

As was to be expected, in 2014, the number of competitive candidacies for state governorships was less. The state with the largest effective number of competitors was Rio de Janeiro (3.8). At the other extreme was Pernambuco, with 1.8 competitors. The national average was 2.6 , which was almost identical to the average for the entire 1982-2014 period (2.5).

The value is smaller than that for presidential elections (Table 01), but nevertheless, it is far from indicating a more closed market. On the contrary-a study conducted by Melo (to be published) for the period between 1994 and 2014 shows that the parties that polarized state elections changed very frequently. In only nine states the same parties were in first or second place from at least half of 
the elections considered. In six of these cases, the pattern observed was similar to the national one. In the others, the PMDB made the difference. In the states of Minas Gerais, São Paulo, Pará, and Mato Grosso do Sul, the PT and the PSDB acquired the first position in three elections. In Bahia, the PT and DEM were the principal protagonists on four occasions, and in Sergipe, the situation repeated itself three times. In five disputes in Rio Grande do Sul, the PMDB had the PT as its principal adversary. In Santa Catarina and in Goiás, the party confronted the PP and the PSDB in four elections each ${ }^{12}$.

Three reasons may be given for the greater openness of the state electoral market vis a vis the national one: the cost of conducting an electoral dispute, evidently less in the first case; the migration of local political bosses, which can change the correlation of forces among the parties of an election to another; and the absence of a competitive candidacy of the PT and / or PSDB in some states. But while the first two reasons are self-explanatory, for the third case two possibilities have to be considered. On the one hand, the absence of a competitive candidate can simply be the result of weakness of one of the two parties, or of both, in the state in question. On the other hand, the PT and/or PSDB may have coordinated the action with their allies on the national level (CORTEZ, 2011), trading the local candidacy for national support.

In the varied Brazilian state scenario, the PMDB is the party that possesses the best conditions to launch competitive candidates. In 2014, there were eighteen candidates with more than $10 \%$ of valid votes. As would be expected, it was the party that most opposed the PT and the PSDB in disputes for state governorships. The latter, for their part, offered fifteen and ten candidacies respectively. This was

12 Of the ten states with the largest number of voters in the country, six are among those mentioned above (São Paulo, Minas Gerais, Bahia, Rio Grande do Sul, Pará and Santa Catarina). The other four-Rio de Janeiro, Paraná, Pernambuco and Ceará - showed less stable electoral situations. Rio de Janeiro, together with Amapá, Alagoas, Mato Grosso and Espírito Santo, forms a set of federal units where it was not possible to observe any pattern in the competition for the state governorship. The other three join the thirteen remaining states, and are in an intermediary position. The alternation among the protagonists therein is greater than that observed in the first group mentioned, but it was possible to identify the presence of the same party as one of the principal protagonists in four of the six elections analyzed. Other proof in the sense of a more open market is given by the variation in the index of volatility in the elections for state governorships. For the period between 1990 and 2014 Rio Grande do Sul and Bahia had indices of 33.2 and 34.4 while Rio de Janeiro and Mato Grosso had volatilities of 61.4 and 75.6. All of the calculations were carried out by the author based on Federal Election Commission data. 
followed by the PSB, with eight competitive candidates. The other parties appeared intermittently: PSD, PDT, and PP were present in two states each, while DEM, Republican Party of Social Order (PROS), PR, PCdoB, PTB, PRB, Christian Social Party (PSC) and Solidarity (SD) were present in one state. The most recurring polarization-present in the states of Goiás, Pará, Paraná, Rondônia and São Paulo-was that involving the PMDB and PSDB. In three states (Rio Grande do Sul, Ceará and Piauí), the main adversary of the PMDB was the PT. And finally, although they directly confronted each other in nine federal units, the PT and PSDB were in the first two places in only three of them (Minas Gerais, Mato Grosso do Sul and Acre). In other words, oscillation of the force of parties in the north and south of the country must be considered when one discusses the reasons why the pattern observed in the dispute for the Presidency was repeated in a limited number of states.

On the other hand, exchanging support, and thus subordinating the state dynamic to the national one makes complete sense for the PT and PSDB but is not always possible. In 2014, the national allies PT and PMDB were in the same coalition in nine states, while in another ten, each party launched its own candidate. The difficulty also appeared on the other side. The DEM and the PSDB joined forces on sixteen occasions but were on opposite sides in another eleven. One can argue that the existence of two state candidacies would be beneficial to the presidential candidate, but this depends on whether the two candidates for governor had similar preferences, which is not always the case. Moreover, those who accompany the process of negotiation between parties know that this situation corresponds to plan $B$, being preceded, in the great majority of cases, by attempts to unify the state campaign ${ }^{13}$.

13 The PT and PMDB were allied in the states of Alagoas, Amazonas, Maranhão, Mato Grosso, Minas Gerais, Sergipe and Tocantins, as well as the Federal District, and faced one another in the states of Ceará, Mato Grosso do Sul, Piauí, Paraná, Rio de Janeiro, Rondônia, Rio Grande do Sul and São Paulo. In Rio Grande do Sul, the PMDB candidate explicitly supported Aécio Neves (PSDB). In Ceará and in Piauí, the PSDB was part of an electoral coalition of gubernatorial candidates of the PMDB. In Rio de Janeiro and in São Paulo, conflicts around candidacies occured before and during the campaign. The PSDB and the DEM were on opposite sides in the states of Alagoas, Maranhão, Roraima, Rio Grande do Sul, Santa Catarina, Goiás, Pará, Paraíba, Acre and in the Federal District. In the six later states, the PSDB had its own candidate. 
Table 03 illustrates how the principal parties created coalitions in elections for state governorships. One immediately notices that the PT and PSDB remained in different coalitions, although as we have observed, this did not always imply that they would be the leading parties. Moreover, the Communist Party of Brazil (PCdoB), the Republican Party of the Social Order (PROS), and the PDT gave priority to alliances with the PT. Changing their names, the same is the case for the DEM, the SD, and the PPS, allies of the PSDB in nearly $60 \%$ of the states, and rarely seen together with the PT. With due caution with regard to the PROS, the picture for 2014 permits us to continue speaking about two blocks, with four parties each, and in a situation where each of the parties presents greater interaction with its allies than with "the other side"14. The fact that the PT and the PMDB remained systematically on opposite sides and continued to attract their principal allies allows us to speak about a process of "presidentialization" of state disputes. The other data indicate their limits ${ }^{15}$.

It is worthwhile examining the change in the behavior of the PSB. As was to be expected, the launching of the party's own presidential candidate provoked a considerable distancing from it on the part of the PT: there were five coalitions in 2014 compared to the eighteen in 2010. However, the data also reveal the preferential choice contained in the "new politics": in eleven states, the party supported the PSDB, more than twice the alliances carried out in 2010. Finally, for the block of "available parties" (MELO and CÂMARA, 2012)-those which prefer to support the winning side of the presidential dispute on the national level-the election for state governor signifies an opportunity to broaden the range of available strategies. In these cases, the national logic counts for less, and a possible "presidentialization" of policy is subordinated to strictly regional trajectories and/or calculations. In the end, the PMDB and PTB were equally linked to the PT

14 The main motivation for the creation of the PROS, in 2013, was the need felt by the brothers Ciro and Cid Gomes (Ceará state governor) to reach a reaccomodation in the face of the decision made by Eduardo Campos to break with the PT and launch his candidacy for the presidency. At the same time, a dissident faction of the PDT, led by Congressman Paulinho da Força, produced the SD, a party that came to adopt a position in opposition to the current administration.

15 In a recent study, Freitas and Neto (2014) propose the creation of a "presidentialization index", with the objective of assessing the impact of the presidential dispute on state races. The initiative is a good one, and contributes to the debate. What needs to be discussed more is the weight given to indicators used in making up the index, since such weight can have considerable impact on the results found. 
and the PSDB. The PR, PSD, and PP clearly tended to lean toward the side of the PSDB, despite having supported the Dilma administration and integrated their coalition in the 2014 presidential election.

Table 03. Parties and coalitions for gubernatorial elections (2014)

\begin{tabular}{lllllllllllllll}
\hline & PT & PCdoB & PDT & PROS & PTB & PMDB & PR & PSD & PP & PSB & DEM & SD & PPS & PSDB \\
PT & & $\mathbf{2 0}$ & $\mathbf{1 3}$ & $\mathbf{1 0}$ & $\mathbf{1 0}$ & $\mathbf{0 9}$ & $\mathbf{0 8}$ & $\mathbf{0 7}$ & $\mathbf{0 6}$ & $\mathbf{0 5}$ & $\mathbf{0 3}$ & $\mathbf{0 3}$ & $\mathbf{0 1}$ & $\mathbf{0}$ \\
PCdo & $\mathbf{2 0}$ & & 15 & 13 & 06 & 13 & 09 & 08 & 07 & 10 & 06 & 04 & 04 & $\mathbf{0 3}$ \\
B & & & & & & & & & & & & & & \\
PDT & $\mathbf{1 3}$ & 15 & & 09 & 08 & 09 & 08 & 10 & 09 & 06 & 07 & 04 & 04 & $\mathbf{0 7}$ \\
PROS & $\mathbf{1 0}$ & 13 & 09 & & 08 & 12 & 13 & 10 & 07 & 07 & 08 & 07 & 06 & $\mathbf{0 4}$ \\
PTB & $\mathbf{1 0}$ & 07 & 08 & 08 & & 05 & 12 & 10 & 17 & 05 & 05 & 06 & 09 & $\mathbf{1 0}$ \\
PMD & $\mathbf{0 9}$ & 13 & 09 & 12 & 05 & & 08 & 12 & 08 & 07 & 10 & 07 & 09 & $\mathbf{0 9}$ \\
B & & & & & & & & & & & & & & \\
PR & $\mathbf{0 8}$ & 09 & 08 & 13 & 12 & 08 & & 13 & 13 & 05 & 11 & 10 & 10 & $\mathbf{1 2}$ \\
PSD & $\mathbf{0 7}$ & 08 & 10 & 10 & 10 & 12 & 13 & & 11 & 08 & 13 & 13 & 12 & $\mathbf{1 4}$ \\
PP & $\mathbf{0 6}$ & 07 & 09 & 07 & 17 & 08 & 13 & 11 & & 07 & 07 & 12 & 14 & $\mathbf{1 4}$ \\
PSB & $\mathbf{0 5}$ & 10 & 06 & 07 & 05 & 07 & 05 & 08 & 07 & & 09 & 10 & 11 & $\mathbf{1 1}$ \\
DEM & $\mathbf{0 3}$ & 06 & 07 & 08 & 05 & 10 & 11 & 13 & 07 & 09 & & 11 & 11 & $\mathbf{1 6}$ \\
SD & $\mathbf{0 3}$ & 04 & 04 & 07 & 06 & 07 & 10 & 13 & 12 & 10 & 11 & & 12 & $\mathbf{1 7}$ \\
PPS & $\mathbf{0 1}$ & 04 & 04 & 06 & 09 & 09 & 10 & 12 & 14 & 11 & 11 & 12 & & $\mathbf{1 7}$ \\
PSDB & $\mathbf{0}$ & $\mathbf{0 3}$ & $\mathbf{0 7}$ & $\mathbf{0 4}$ & $\mathbf{1 0}$ & $\mathbf{0 9}$ & $\mathbf{1 2}$ & $\mathbf{1 4}$ & $\mathbf{1 4}$ & $\mathbf{1 1}$ & $\mathbf{1 6}$ & $\mathbf{1 7}$ & $\mathbf{1 7}$ \\
\hline
\end{tabular}

Source: Federal Election Commission data (TSE).

\section{Presidential elections and legislative fragmentation}

After the contributions of Shugart and Carey (1992), Jones (1995) and Mainwaring and Shugart (1997), discussion occurred in the literature regarding the impact of majoritarian elections on proportional ones. According to the authors, there was a coattail effect of the presidential election on the party system, depending upon the combination between the electoral cycle and the formula adopted for choosing the Executive: since the choice of the President is made through plurality and coincides with the election for Congress, the party system tends to be dominated by two large parties, even when the Legislative branch is formed based on proportional representation.

In Brazil, elections have been simultaneous since 1994, but the presidential dispute is conducted in two rounds, which according to Carey and Shugart, would tend to make the system arrange a multi-party format already on the presidential level, since the parties would be stimulated to launch candidates with the objective of increasing their representation in the legislature. Such a tendency, as we have shown, has not been the case in Brazil. Here, therefore, the 
low number of candidates, plus the introduction of re-election since 1998, may have contributed to the reducing effect of presidential elections ${ }^{16}$.

However, even after 20 years of clear hegemony in the sphere of presidential elections, the PT and PSDB did not witness any increase in their representation in the Chamber of Deputies. The former grew until 2002, when it reached $17.7 \%$ of elected representatives, but the number oscillated in the subsequent elections and fell in the election under analysis herein. The PSDB dropped from $19.3 \%$ of the seats in the Chamber of Deputies in 1998 to $10.5 \%$ in 2014. Twenty years and six consecutive elections should have furnished the time necessary for a significant part of the electorate to adopt national elections as an informational shortcut and to associate their votes in disputes for the executive and legislative branches.

However, this is not what happened: on the contrary, the 2014 election continued the trend of high levels of legislative fragmentation in the country. A part of the explanation is that it was due to the appearance of three new parties during the 2011-2015 legislative period. In 2013, the records of the Chamber of Deputies indicate that the PSD, SD, and the PROS controlled 7.8\%, 4.1\%, and 3.5\% of seats, respectively. Beginning in 2015, if new changes do not occur, the legislature will contain 28 of the 32 political parties registered with the Federal Elections Commission and the effective number of parties will reach 13.3, a number which is difficult to approach within the scenario of contemporary democracies ${ }^{17}$. The party with the largest number of representatives, the PT, will control only $13.6 \%$ of the seats, a percentage similar to the number of representatives elected by fourteen small and micro parties with representation in Congress. The situation repeated itself in the Federal Senate, where the effective number of political parties also increased, reaching 8.4. It should be noted that since this second legislative body is elected by the majoritarian method, it is not possible to assume the proportional representation system as the principal factor to blame for the level of fragmentation within Congress.

${ }^{16}$ According to Golder (2006), simultaneous elections only produce a reductive effect over proportional elections if associated with a low number of candidates in presidential elections.

17 Between 1982 and 2014, the variation of the indicator was the following: $2.4 ; 2.8 ; 8.7$; 8.2; 7.1; 8.5; 9.3; 10.8 and 13.3. Calculations conducted by the author. 
One of the reasons that presidential disputes do not have an impact on the party system in the legislative branch may be observed in the federative organization of the country and in the fact that national and state elections coincide. In other words, the impact of presidential elections on party performance would be neutralized by the effect of the election of governors; a hypothesis defended by Samuels (2003). Once again, as a limitation of this study we do not have the intention to submit such a hypothesis for testing but it is possible to offer some thoughts.

On the one hand, it seems evident that good performance in gubernatorial elections has an impact on the parties elected to Congress. This is, going back to the argument of Schugart and Carey (1992), one of the reasons wherein Brazilian parties (which use the two-round format) do not need to launch candidates in presidential elections with the intention of reinforcing their representation in Congress: they can produce a similar result thanks to the simultaneity of elections for governors and that of Congress. In other words, launching their own candidates or even participating in competitive coalitions in various states contributes to the growth of their representation in Congress. We have noted that among all of the Brazilian parties, the PMDB is the party that has the most favorable conditions to put this strategy into practice.

But, on the other hand, at least one piece of data appears to indicate that even in states, the "coattail effect" of the majoritarian election is not very strong: in 2014 , the victorious parties in gubernatorial elections obtained, on an average, $49.7 \%$ of votes in the first round but merely $13.7 \%$ of votes for their respective state legislative assemblies. The difference is very similar to that observed in 2010 , when victorious candidates received $51.7 \%$ in the first round, while their parties won $14.9 \%$ in the legislative assemblies. And even in those states where incumbents were reelected in 2014 and the parties returned to control the state, the average was just $18 \%$ of voting for the assembly ${ }^{18}$, which is not high.

The paradox between the two points raised above is only apparent. This is because good performance at the state level, in an overwhelming majority of cases, helps to elect "state party representations" of small size that, once aggregated,

18 The states in which parties were returned to power were Acre, Bahia, Goiás, Pará, Paraíba, Pernambuco, Paraná, Rondônia and São Paulo. All calculations were performed by the author, based on data of the Federal Elections Commission. 
contribute to the party having weight in the Congress. However, when one considers states as the unit of analysis, and, in particular, those that send large party representations to Congress, there are rare cases wherein a party is able to send a group that surpasses $30 \%$ of available seats ${ }^{19}$.

At the state level, this situation occurs within a context in which the degree of fragmentation, such as that which occurs in the Chamber of Deputies, continues to increase. Data collected by Ferreira, Batista and Stabile (2008) indicate that in 1994, the effective number of parties in state legislative assemblies was 6.9 on an average. After the 2014 election, the average number of effective parties will be 10.8, with Santa Catarina having the lowest value (6.4) and Maranhão the highest (18.1).

If reasons exist to think that the coattail effect in voting for governors has not been strong, the explanation for the evident divorce between the results of elections for the presidency and those of the Congress may lie in other factorsone of a sociological nature and the other institutional. In the first case, the absence of parties that anchored in reasonable levels of party identification comprise a "system of canalization" of the aspirations of the electorate (SARTORI, 1996), forming an electoral market that is excessively open, frequented mostly by "available" voters, and where parties of all kinds find a place. In a context such as this, it would not be expected that the majority of voters would be able to minimally distinguish between the parties in dispute in order to place a strategic vote. If such a context has not impeded the Brazilian electorate from concentrating its votes among the PT and the PSDB in presidential elections, as is evident, this cannot be explained by the social roots of these parties, but rather through the fact that they, for reasons already explained, have controlled the dispute, making the entry of other competitors ${ }^{20}$ an expensive measure.

${ }^{19}$ Between 1994 and 2014, considering the states that sent the largest party groups to the Chamber of Deputies (SP, RJ, MG, BA, PR, RS, PE and CE), there were few parties that surpassed this figure. In 1994, 1998 and 2002, the PFL surpassed it in Bahia and the PSDB, in Ceará; in 2006, the PFL surpassed it once again in Bahia, and in 2014, the PROS in Ceará and the PSB in Pernambuco.

${ }^{20}$ Although research shows that slightly more than $20 \%$ of the electorate identifies with the PT, the same is not the case for the PSDB, which passes the mark of $5 \%$ with much difficulty (SAMUELS AND ZUCCO, 2014). The Brazilian case fits into the situation described by Luna and Altman (2011), in which a party system finds itself institutionalized 
For its part, a set of characteristics of the Brazilian electoral system completes the scenario. Operating within large districts, the system places hardly any important barriers to legislative access. The only existing one, the electoral quotient, is easily bypassed by coalitions. These, besides contributing to fragmentation (a simulation conducted by the DIAP demonstrates that the effective number of parties would drop to 8.5 in the Chamber of Deputies if such coalitions were prohibited ${ }^{23}$ ) would also make it more difficult for majority system candidates to conduct voting for their parties in the elections for the legislature ${ }^{21}$. While Dilma Rousseff was supported by nine parties, the same number as Aécio, in the states, the average number of parties comprising coalitions of the two strongest candidates was 10.8 . In both cases, the coalitions contributed to diluting the impact of party affiliation of the majority system candidate over the proportional vote of the candidate's party. Finally, open lists, which stimulate the vote for candidates rather than for parties, decrease the possibility that elections for the executive may serve as informational shortcuts for the voter in terms of votes for the legislative branch.

\section{Conclusion}

In 2014, the combination of the novelty represented by Marina Silva and the groundwork laid by Eduardo Campos resulted in increasing the chances of successfully challenging the hegemony of the PT and the PSDB in presidential elections relatively to the past. Nevertheless, the picture remained unchanged. It is important to emphasize that such a statement does not "reveal" any problems: the pattern acquired by presidential competition resulted in stabilizing the Brazilian political system and advancement in the formulation and development of public policies in the most relevant societal areas. In this sense, the idea of breaking with the "old politics" was never duly grounded and was characterized more as a campaign slogan than anything of substance.

However, the maintenance of two-party control of the presidential race still generates reduced impact over the whole of the party system. It is a fact that in

with regard to electoral stability but not necessarily in that which results in parties being rooted in society.

${ }^{21}$ www.diap.org.br. PT, PMDB, PSDB and PSB would gain, respectively, 36, 32, 14 and 07 chairs. 
the gubernatorial elections, the PT and PSDB remained on opposite sides and brought with them, in the majority of states, their most consistent allies-the PCdoB, PDT and now the PROS, on one side, and the DEM, PPS and the new SD on the other. Nevertheless, the process of the "presidentialization" of the state disputes seems to be limited by the precarious insertion of the PT and the PSDB in various units of the Brazilian Federation and by the presence of their principal competitor in this sphere, the PMDB.

Thus, the 2014 election demonstrated that the Brazilian electoral market, contrary to what happens on the national plain, tends to maintain or increase its degree of opening to various levels. After the election of 2010 , the state scenario seemed to converge four players, once the PMDB, PSDB, PT, and PSB controlled $89 \%$ of state governments. After 2014, however, nine parties will head state governments, which is the most plural scenario since re-democratization.

In the legislative, fragmentation maintained the growth trend. The vast majority of the electorate continues not to see a reason, or not to have a stimulus, to associate the votes given to the executive with choices made for the legislature. Consequently, after twenty years of control over presidential disputes, the PT and the PSDB witnessed no growth in their representation in the legislature. It was, in fact, completely the opposite.

If the arguments presented in this study are correct, there is a strong possibility for the continuation of the two party monopoly. The PSB emerged among the Brazilian parties as the one that seemed to combine the best conditions to change the structure of the competition for the presidency of the republicgiven the characteristics of the PMDB, the decline of the DEM, and the incipient nature of the recently created PSD. The events of 2014, however, may profoundly impact the party. Regardless of being placed third in the dispute, the party will have to recover from the loss of its principal leadership in a context in which the number of elected governors fell by half, and the party will no longer enjoy the resources that were drawn from participation in the governing coalition.

Be that as it may, two party dominance in presidential elections will continue to exist with broad coalitions. In 1998, Fernando Henrique needed only four parties to obtain $67.7 \%$ of votes in the Chamber of Deputies and $85.1 \%$ in the Senate. If Aécio Neves had won the presidency, he would have had to bring 
together ten parties to acquire $64.8 \%$ of votes in the first case, and $69 \%$ in the second. The coalition formed by Dilma for her second administration initially had nine parties ${ }^{22}$.

One may add a context of radicalization to the problem of fragmentation with consequences that are not completely predictable. The rising of tempers during the 2014 campaign and the defeat by a small margin, frustrating the prospect of a change in govern, caused the PSDB to give ambiguous signals in terms of its recognition of the electoral result. First, there was an unconvincing demand for a recount. The request resulted in procedures adopted by the Federal Elections Commission; however, strangely, it expressed doubts only with regard to the second round, ignoring the first one when the candidate of the party had a meteoric rise during the final days of the campaign. Later, Aécio Neves declared to the press that he had been defeated by a "criminal organization"23 and his supporters held protests in São Paulo, wherein the proposal for a "white coup" (an impeachment without legal foundation) was combined with calls for a military intervention ${ }^{24}$. Finally, the party requested that the Federal Elections Commission declare Dilma's election invalid, alleging that her legitimacy is "extremely tenuous"25. Increasingly conservative in content, the PSDB now flirts with the old tactic of the UDN, which did not know that in democracies, "parties lose elections".

Translated by Cabo Verde Submitted in December 2014

Accepted in February 2015

\section{References}

COX, Gary (1997), Making Votes Count - Strategic Coordination in the World's Electoral Systems. New York: Cambridge University Press.

CORTEZ, Rafael (2011), o sistema partidário eleitoral à luz da coordenação eleitoral: a relação entre o pleito presidencial e estadual no Brasil (19892010). Paper delivered at the 360 Encontro Anual da ANPOCS.

DATAFOLHA (2014), Marina empate técnico com Dilma. www1.folha.uol.com.br. Access in October 12, 2014.

22 PT, PMDB, PSD, PDT, PP, PR, PRB, PROS e PC do B.

${ }^{23} \mathrm{http}: / /$ G1.globo.com.

${ }^{24} \mathrm{http}: / /$ G1.globo.com.

25 www1.folha.uol.com.br. 
DIAP (2014), Cadeiras no legislativo por partido. www.diap.org.br. Access in December 1st, 2014.

DUVERGER, Maurice (1987), Os Partidos Políticos. Rio de Janeiro: Ed. Guanabara.

FEDERAL ELECTION COMMISSION DATA. www.tse.jus.br.

FERREIRA, Denise; BATISTA, Carlos and STABILE, Max (2008), A evolução do sistema partidário brasileiro: número de partidos e votação no plano subnacional. Opinião Pública. Vol. 14, № 02, pp. 432-453.

FOLHA DE SÃO PAULO (2014), Relação entre os votos de Marina e Dilma. www1.folha.uol.com.br. Access in December 10, 2014.

FOLHA DE SÃO PAULO (2014). Choro de perdedor. www1.folha.uol.com.br. Access in December 21, 2014.

FREITAS, Vitor e NETO, Fernando Augusto (2014), Qualitative Comparative Analysis (QCA): usos, possibilidades e limites para a análise da dinâmica da competição eleitoral no Brasil pós-1994. Paper delivered at IX Encontro da Associação Brasileira de Ciência Política. Brasília.

GOLDER, Matt (2006), Presidential Coattails and Legislative Fragmentation. American Journal of Political Science. Vol 50, № 01, pp. 34-48.

JORNAL O GLOBO (2014). Eu perdi para uma organização criminosa. http://G1.globo.com. Access in November 11, 014.

JORNAL O GLOBO (2014). Ato em São Paulo reúne protestos contra Dilma, os desvios na Petrobras e a votação da meta fiscal. http://G1.globo.com. Access in June 12, 2014.

LIMA JUNIOR, Olavo Brasil (1999), Eleições Presidenciais: Centralidade, Contexto e Implicações. Revista Brasileira de Ciências Sociais. Vol. 14, № 40, pp. 11- 30.

LIMONGI, F. e CORTEZ, Rafael (2010), As eleições de 2010 e o quadro partidário. Novos Estudos. № 88, pp. 21-37.

LUNA, Juan Pablo e ALTMAN, David (2011), Uprooted but Stable: Chilean Parties and the Concept of Party System Institutionalization. Latin American Politics and Society. Vol. 53, № 02, pp. 1-28.

JONES, Mark (1995), Electoral Laws and the Survival of Presidential Democracies. Notre Dame: University of Notre Dame Press.

MAINWARING, Scott and SHUGART, Matthew (eds.) (1997), Presidentialism and Democracy in Latin America. Cambridge: Cambridge University Press. 
MAIR, Peter (1996), Party Systems and Structures of Competition. In: LEDUC, Lawrence; NIEMI, Richard G. and NORRIS, Pippa (orgs.), Comparing Democracies - Elections and Voting in Global Perspective. London: Sage Publications.

MAIR, Peter (2006), Party system change. In: KATZ, Richard and CROTTY, William (eds.), Handbook of Party Politics. London: Sage Publications.

MEIRA, Francisco (2013), Um Brasil na TV: efeitos de campanha nas eleições presidenciais brasileiras (1989 - 2010). PhD Dissertation, Political Science Department, UFMG.

MELO, Carlos Ranulfo (2010), Eleições presidenciais, jogos aninhados e sistema partidário no Brasil. Revista Brasileira de Ciência Política. № 04, pp. 13-41.

MELO, C. R. e CÂMARA, Rafael (2012), Estrutura da Competição pela Presidência e Consolidação do Sistema Partidário no Brasil. Dados. Vol. 55, № 01, pp. 71-117.

RIBEIRO, Pedro Floriano (2013), Organização e poder nos partidos brasileiros: uma análise dos estatutos. Revista Brasileira de Ciência Política. № 10, pp. 225265.

ROMA, Celso (2002). A Institucionalização do PSDB entre 1988 e 1998. Revista Brasileira de Ciências Sociais. Vol. 49, pp. 71-92.

SAMUELS, David (2003), Ambition, Federalism and Legislative Politics in Brazil. New York: Cambridge University Press.

SAMUELS, D. and ZUCCO, Cesar (2014), Crafting Mass Partisanship at the Grass Roots. British Journal of Political Science. Vol. 26, pp. 01-21.

SARTORI, Giovanni (1996), Engenharia Constitucional. Brasília: UNB.

SHUGART, Matthew and CAREY, John (1992), Presidents and Assemblies: Constitutional Design and Electoral Dynamics. Cambridge: Cambridge University Press.

THELEN, Kathleen (1999), Historical Institutionalism in Comparative Politics. Annual Review of Political Science. №02, pp. 369-404. 